\title{
Glacier motion dominated by processes deep in underlying till
}

\author{
M. Truffer, W. D. Harrison, K. A. Eghelmeyer \\ Geophysical Institute, University of Alaska Fairbanks, Fairbanks, Alaska 99775-7320, U.S.A.
}

\begin{abstract}
Black Rapids Glacier is a $40 \mathrm{~km}$ long surge-type glacier in the central Alaska Range. In spring 1997 a wireline drill rig was set up at a location where the measured surface velocities are high and seasonal and annual velocity variations are large. The drilling revealed a layer of subglacial "till", up to $7 \mathrm{~m}$ thick, that is believed to be water-saturated. At one location a string of instruments, containing three dual-axis tiltmeters and one piezometer, was successfully introduced into the till. The tiltmeters monitored the inclination of the borehole at the ice-till interface and at 1 and $2 \mathrm{~m}$ into the till, for 410 days. They showed that no significant deformation occurred in the upper $2 \mathrm{~m}$ of the till layer, and no significant amount of the basal motion was due to sliding of the ice over the till. The measured surface velocity at the drill site is about $60 \mathrm{~m} \mathrm{a}^{-1}$, of which $20-30 \mathrm{~m} \mathrm{a}^{-1}$ can be accounted for by ice deformation. Almost the entire amount of basal motion, 30-40 $\mathrm{m} \mathrm{a}^{-1}$, was taken up at a depth of $>2 \mathrm{~m}$ in the till, possibly in discrete shear layers, or as sliding of till over the underlying bedrock. We propose that the large-scale mobilization of such till layers is a key factor in initiating glacier surges.
\end{abstract}

\section{INTRODUCTION}

Early models of basal motion commonly assumed that glaciers were underlain by clean bedrock. Some borehole studies, however, showed the presence of a layer of sediments beneath the ice (Engelhardt and others, 1978). The importance of such a layer for glacier dynamics was demonstrated by the work of Boulton and Hindmarsh (1987) who measured the positions of strain markers and pore-water pressures in a sediment layer beneath the terminus of Breidamerkurjökull, Iceland, and by Echelmeyer and Wang (1987), who measured the distribution of basal motion in a tunnel at the terminus of Ürümqi Glacier No. 1, China. Interest in till deformation was stimulated by the evidence for a water-saturated till layer beneath Ice Stream B, Antarctica (Blankenship and others, 1986), that was interpreted to be soft and deforming (Alley and others, 1986). ${ }^{1}$ In a subsequent drilling effort, samples of the underlying till were recovered, and high basal water pressures - within about $160 \mathrm{kPa}$ of the ice-overburden pressure - were measured (Engelhardt and others, 1990).

Although the importance of subglacial till in glacier motion has been recognized, there remains controversy about its rheology. Boulton and Hindmarsh (1987) concluded that till was deforming like a nearly linear viscous fluid. Kamb's (1991) tests on Ice Stream B samples suggested a highly non-linear behavior. Iverson and others (1998) summarized several shear tests carried on to high strains in a ring-shear apparatus. They show a shear strength of the material that is essentially strainrate independent, i.e. a Coulomb-plastic rheology. The consequences of such a rheology for subglacial material have been examined by Tulaczyk (1999) and Tulaczyk and others (2000).

1 In this paper we will call all unlithified subglacial material "till", irrespective of its origin.
They and Iverson and others (1998) also pointed out that a Coulomb-plastic rheology can produce distributed motion in a till layer.

Several instruments have been developed for in situ studies of subglacial sediments: borehole cameras (Harrison and Kamb, 1973), tiltmeters, pore-pressure transducers, drag spools and ploughmeters (Blake and others, 1992, 1994; Fischer and Clarke, 1994). Work with a combination of such instruments has suggested that, at least in some cases, episodes of fast motion are caused by sliding of ice over till and not by till deformation (Hooke and others, 1997). Engelhardt and Kamb (1998) used a tethered stake to conclude that the major part of the observed surface velocity at Ice Stream B was due to sliding of ice over till, or possibly deformation of a very thin $(3 \mathrm{~cm}$ thick $)$ till layer.

Observations of subglacial till have also been made in tunnels cut into the ice in the terminal area of glaciers. Boulton and Hindmarsh (1987) observed distributed motion in the uppermost $50 \mathrm{~cm}$ of the till that accounted for $80-95 \%$ of the observed glacier motion. Echelmeyer and Wang (1987) showed that $60-85 \%$ of the motion of sub-freezing Ürümqi Glacier No. 1 was due to basal processes: enhanced deformation of ice-laden till, motion across discrete shear planes, and basal sliding at the ice-till interface. Motion across shear bands and planes accounted for $10-25 \%$ of the total glacier motion. Sliding of ice over bedrock or till, till deformation and faulting within the till, and perhaps even sliding of till over underlying bedrock have all been suggested as mechanisms of basal motion (e.g. Knight, 1999, fig. 7.1), although the relative magnitudes of these processes remain uncertain.

In this paper we use data from one location on Black Rapids Glacier, Alaska, U.S.A., to investigate the contribution of basal motion to the observed surface motion of the glacier. Detailed measurements allow us to ascertain 
where in the basal layer this component of motion is occurring. The implications of our findings are then discussed in terms of till deformation and also surge initiation.

\section{SETTING}

Black Rapids Glacier is a $40 \mathrm{~km}$ long surge-type glacier in the central Alaska Range. It last surged in 1936/37. The glacier has been investigated since the early 1970s by the U.S. Geological Survey, the University of Alaska Fairbanks and the University of Washington. Heinrichs and others (1996) describe the glacier in its quiescent state. More recent work includes a seismic study (Nolan and Echelmeyer, 1999a, b) in which changes in the seismic return signal on very short time-scales - as little as half an hour - were observed. They could explain this observation only with drastic changes in the overburden pressure on a water-saturated till layer which was at least $5 \mathrm{~m}$ thick. These changes occurred as a result of the draining of marginal lakes.

In spring 1997 a wireline drill rig was set up about $15 \mathrm{~km}$ from the head of the glacier in an effort to sample basal ice, subglacial till and underlying bedrock (Truffer and others, 1999). This is the area of the glacier where the velocities are high, where large seasonal and annual velocity variations are observed (Heinrichs and others, 1996) and where the above-mentioned seismic study was carried out. The glacier's maximum thickness is $>600 \mathrm{~m}$ at that location, and the surface slope is about $2^{\circ}$. Drilling to bedrock was successful in two places, where we measured a thickness of the till layer of $7.5 \mathrm{~m}$ at $\mathrm{Nl}$ and $4.5 \mathrm{~m}$ at Center (Fig. 1; Truffer and others, 1999). Basal ice, containing some dirt layers, was clearly separated from the underlying till. The upper few centimeters or decimeters of till did contain some ice, however. A sample of till matrix recovered from the top of the till layer underwent several soil engineering tests (see below: "Engineering properties of a till sample").

A string of three tiltmeters and one piezometer was installed in borehole N1A (Fig. 1). At that location the ice thickness was $499 \mathrm{~m}$. This paper concentrates on the results of this borehole experiment.

\section{METHODS}

In this section we discuss the methods used to measure surface

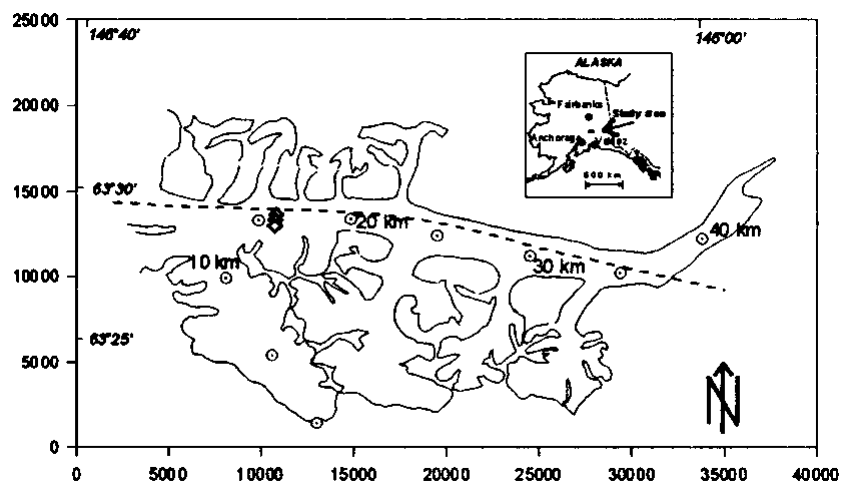

Fig. 1. Black Rapids Glacier. Map of the glacier and the study area. The diamonds show the boreholes $\mathcal{N} 1$, Center and S1 (from top), and the circles are located every $5 \mathrm{~km}$ along a center-line coordinate system. The approximate trace of the Denali Fault is outlined by the dashed line. The axes outline a local coordinate system; units are in meters. motion, ice deformation, motion of the underlying till and water pressure. The results are reported in the next section.

\section{Surface motion and deformation of the ice}

The glacier's surface motion at the drill site was measured over various time-scales. The annual displacement of the borehole marker was measured by resection with a theodolite. In June 1997 a global positioning system (GPS) receiver recorded the position of a nearby stake four times a day for 3 weeks. Upstream of the drill site a camera has taken one picture a day since 1986 to record the motion of a pole.

Internal ice deformation in borehole $\mathrm{Nl}$ (located $10 \mathrm{~m}$ to the north of N1A) was measured with a retrievable inclinometer equipped with two mutually perpendicular tilt sensors and a compass. The inclinometry was performed on 16 May, 1 June and 28 June 1997.

\section{Measurements within the till}

Three tiltmeters were installed near the bed and in the till: the uppermost at the ice-till interface, and the others at 1 and $2 \mathrm{~m}$ below the interface (Fig. 2). This distance was measured from the top of the borehole down, as well as from the bottom up. The total length of the borehole was well known from the wireline drilling. The two methods of measurement were in excellent agreement. The elastic properties of the instrument cable were measured prior to installation, and the $1.5 \mathrm{~m}$ stretch of the cable due to a $20 \mathrm{~kg}$ load at its end was taken into account. The buoyant weight of the cable was $20 \mathrm{~kg}$. Potential errors result from additional stretching of the cable due to its own weight, the buoyancy of the steel weight in a drill mud of a density unknown to us, and the possibility of caving-in of parts of the borehole before instrument insertion. These errors add up to a maximum of $0.5 \mathrm{~m}$ in the position of the instruments.

The instruments were mounted on a cable of $1.3 \mathrm{~cm} \mathrm{di}$ ameter (Cortland Cable Company) that was designed to stretch up to $30 \%$ before breaking. We used dual-axis electrolytic tiltmeters (Fredericks) with a measuring range of $0-30^{\circ}$. A data logger (Campbell 21X) recorded tilt along both axes, which was converted to total tilt and azimuth (Fig. 3).

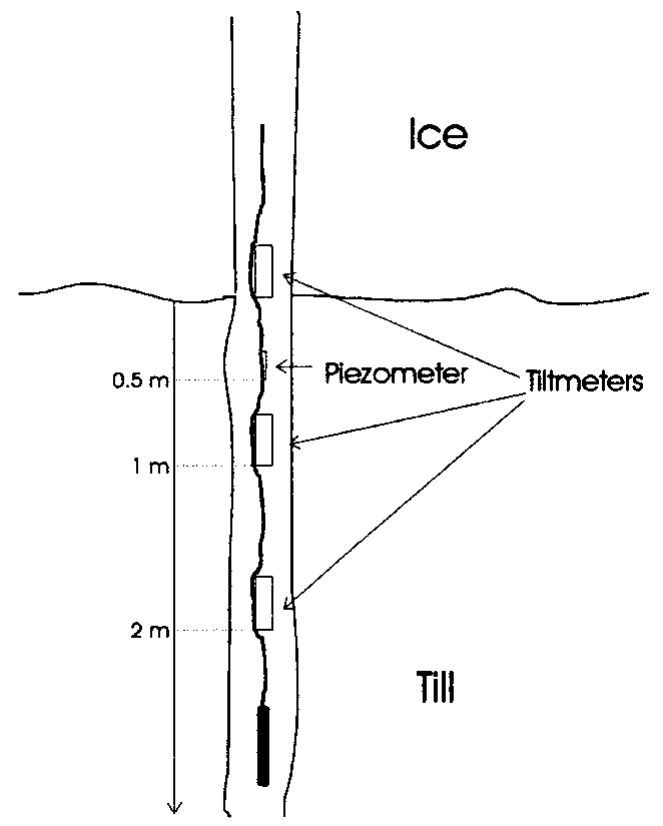

Fig. 2. Schematic drawing of the borehole instruments and their position in the borehole, as discussed in the text. 


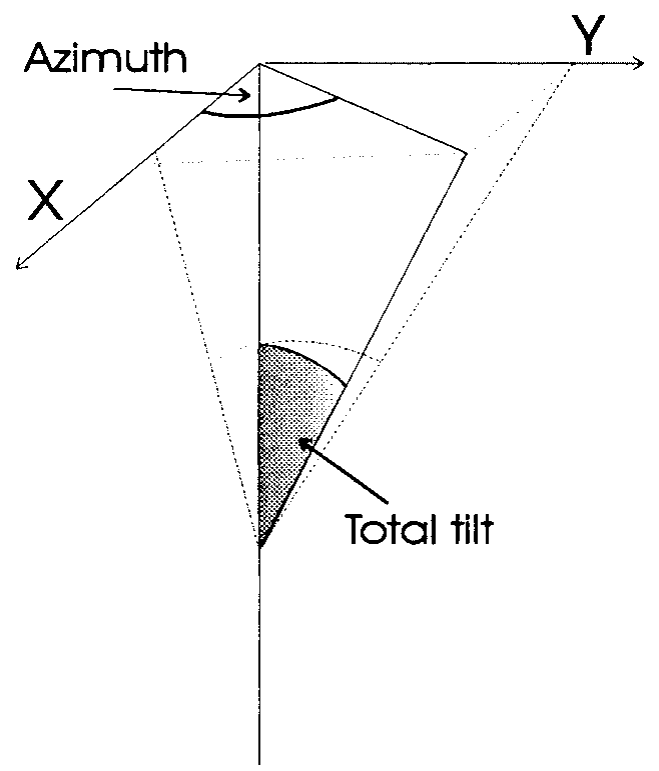

Fig. 3. Tilt is measured along two axes (dotted lines), and then converted into total tilt and azimuth (bold lines).

Changes in azimuth cannot be distinguished from rotation of the instrument around its own axis since no compass was used. We assume that such rotation is small, because it would induce torsion in the short section of cable between the individual instruments. The tiltmeters were mounted in $16 \mathrm{~cm}$ long cylindrical pressure cases, $7 \mathrm{~cm}$ in diameter.

Pore-water pressure was measured with a vibrating wire piezometer (Geokon) $0.5 \mathrm{~m}$ below the ice-till interface. The instrument had a range of $7 \mathrm{MPa}$ and a resolution of $3 \mathrm{kPa}$. Borehole water levels were also recorded with a pressure transducer at $150 \mathrm{~m}$ below the glacier surface. This transducer was less accurate, and subject to systematic errors.

\section{RESULTS}

\section{Surface displacement and ice deformation}

The average annual surface velocity was about $60 \mathrm{ma}^{-1}$ at the borehole location. This implies a surface displacement of almost $70 \mathrm{~m}$ for the 410 days of borehole data collection. The position of a marker $300 \mathrm{~m}$ to the south of the drilling site was measured with a theodolite and an electronic distance meter (EDM) until Julian day (JD) 155, and then four times a day using GPS methods. Figure 4 a shows the horizontal velocity. The spring speed-up on 7 June and several other events are prominent features of the record. The event on 21 June was a result of the drainage of a marginal lake upstream of the drill site, observed by an automatic camera. These events are very well resolved, as the GPS-derived velocities have an error of $<6 \mathrm{~cm} \mathrm{~d}^{-1}$ (see error bar in Fig. 4a).

Only the lowermost $100 \mathrm{~m}$ of the inclinometry record could be interpreted because, apparently, the borehole was too wide in its upper part to yield meaningful results. Assuming that the upper part of the borehole does not contribute significantly to the total deformation, we derived deformational speeds of $19 \mathrm{~m} \mathrm{a}^{-1}$ for the period $16 \mathrm{May}^{-1}$ June, and of $23 \mathrm{~m} \mathrm{a}^{-1}$ for the period 1-28 June. On 7 June 1997 the annual spring speed-up occurred and the surface velocity of the glacier rose by a factor of three (Fig. 4a). This did not significantly affect the results of the inclinometry. A second estimate of deformational speed can be obtained from

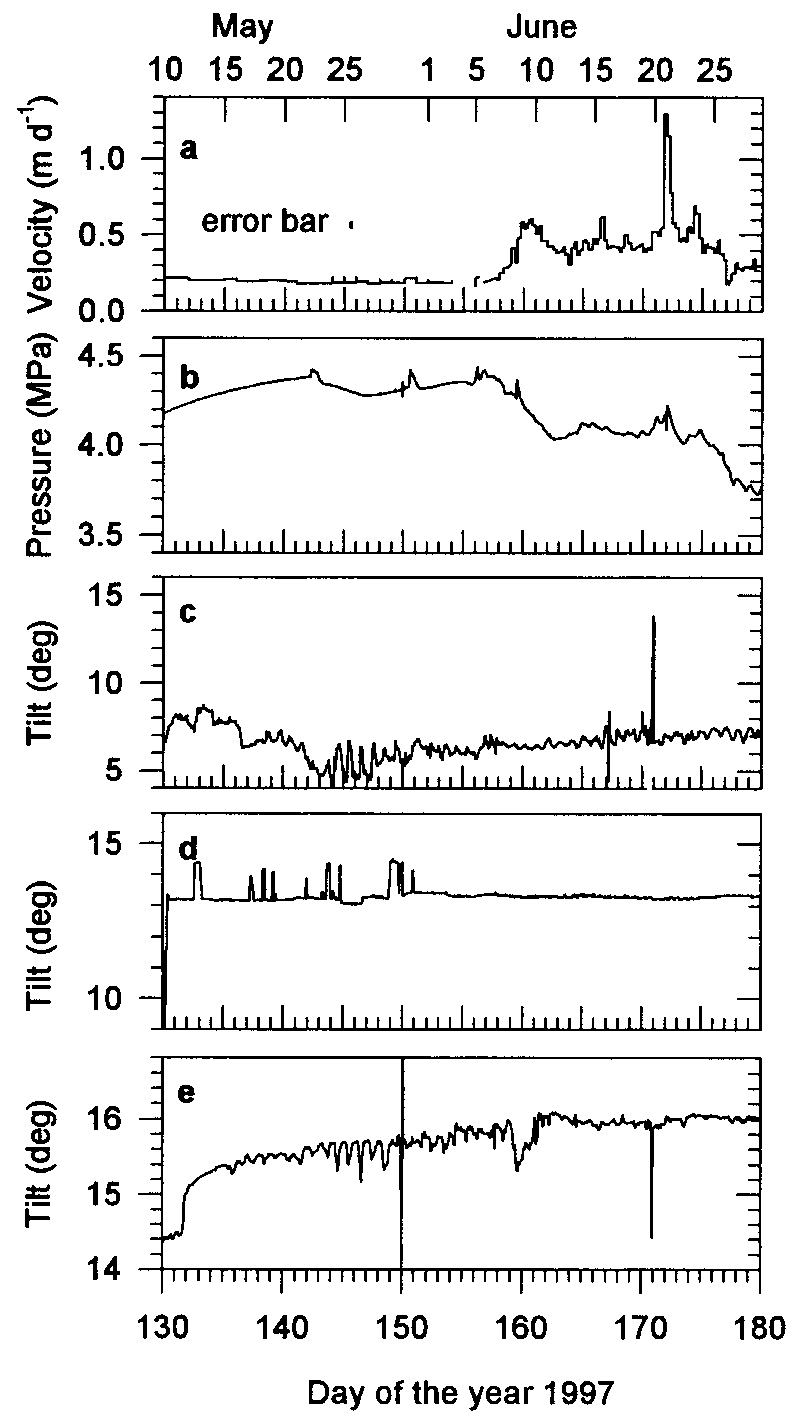

Fig. 4. (a) Velocity measured with theodolite and EDM (before FD 155) and GPS methods (thereafter). (b) Water pressure measured $0.5 \mathrm{~m}$ below the ice-till interface. Total tilt of the tiltmeters at the interface ( $(c), 1 \mathrm{~m}$ below it $(d)$ and $2 \mathrm{~m}$ below it (e). Note the different scales on the ordinate axes.

winter velocities. Minimum observed velocities amount to $35 \mathrm{~m} \mathrm{a}^{-1}$. This is an upper estimate for the deformational speed, because there is reason to believe that basal motion is occurring year-round (Heinrichs and others, 1996). A third estimate, of about $30 \mathrm{~m} \mathrm{a}^{-1}$, was obtained by using a model based on Kamb and Echelmeyer's (1986) longitudinal averaging method. For the remainder of the paper we will assume that $20-30 \mathrm{~m} \mathrm{a}^{-1}$ is due to deformation of the ice. This implies basal motion of $30-40 \mathrm{~m} \mathrm{a}^{-1}$.

\section{Measurements in the till}

Tiltmeter and piezometer data were recorded from 8 May 1997 until 22 June 1998, when water flooded the data-logger box. Data gaps resulted from using up the storage module's memory in summer 1997, and loss of battery power in winter 1998 (Fig. 5). We had expected the cable to break during one of the early speed-up events in spring 1997. The fact that data were still being recorded well over a year after initiation of the experiment came as a major surprise.

Figure 6 shows the tiltmeter records in a projection of the tiltmeter axis on a horizontal plane. The total change in tilt between the first and the last measurement is $3.4^{\circ}$ for 

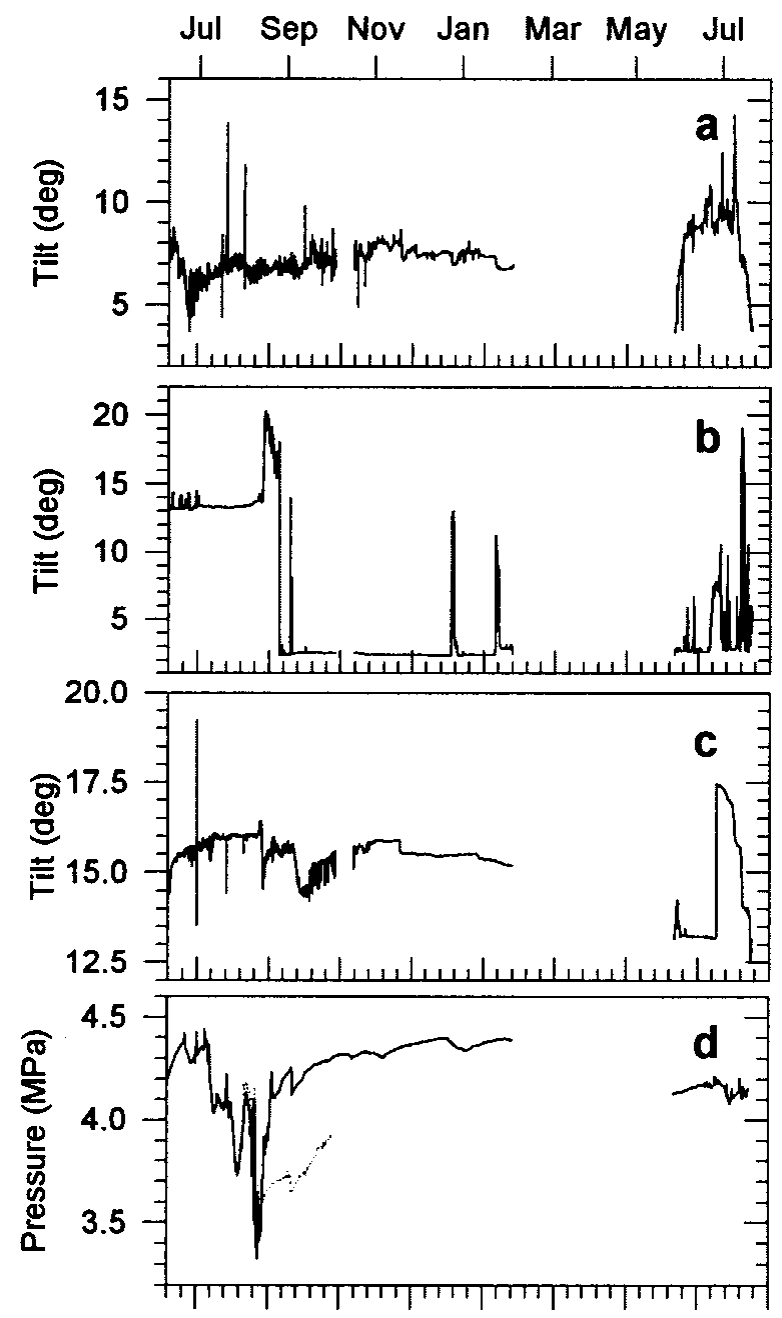

150200250300350400450500550

Day of the year 1997

Fig. 5. Total tilt at the interface ( $a$ ), $1 \mathrm{~m}$ below it ( $b$ ) and $2 \mathrm{~m}$ below it (c). Azimuth is not shown in this graph. (d) Water pressures measured at $0.5 \mathrm{~m}$ below the interface (solid line), and at $150 \mathrm{~m}$ below the glacier surface (dotted line). The borehole water-level record was converted to pressure at the position of the piezometer in the till. They overlap from $7 \mathrm{D} 180$ to $\mathrm{FD}$ 195, when a shift in the water-level record occurs.

the uppermost, $4.9^{\circ}$ for the second and $1.8^{\circ}$ for the lowest tiltmeter, implying $13 \mathrm{~cm}$ of basal motion over the uppermost $2 \mathrm{~m}$ of till.

The small values of total tilt, the fact that the cable was still intact after 410 days, and the estimate of $35-45 \mathrm{~m}$ of basal motion during that time interval lead us to conclude that a major part (50-70\%) of glacier motion occurred below the lowermost tiltmeter, i.e. below $2 \mathrm{~m}$ in the till (Fig. 7).

At times there appears to be larger tilt, but this tilting seems to be a reversible phenomenon. The tiltmeter at $1 \mathrm{~m}$ below the interface shows one jump of about $15^{\circ}$ on JD 207, and then several excursions later on, all in the same direction (Figs 5 and 6). All of the tiltmeters show diurnal variations at times. No permanent tilting is associated with speed-up events (Fig. 4), although the lowermost tiltmeter seems to react to the spring speed-up, and the uppermost and lowermost instruments show strong but reversible spikes prior to the large speed-up event on 21 June (Fig. 4).

Figure $5 \mathrm{~d}$ shows the pore-water pressure record. For about 2 months, water pressures were also simultaneously measured in the borehole at $150 \mathrm{~m}$ below the glacier surface.
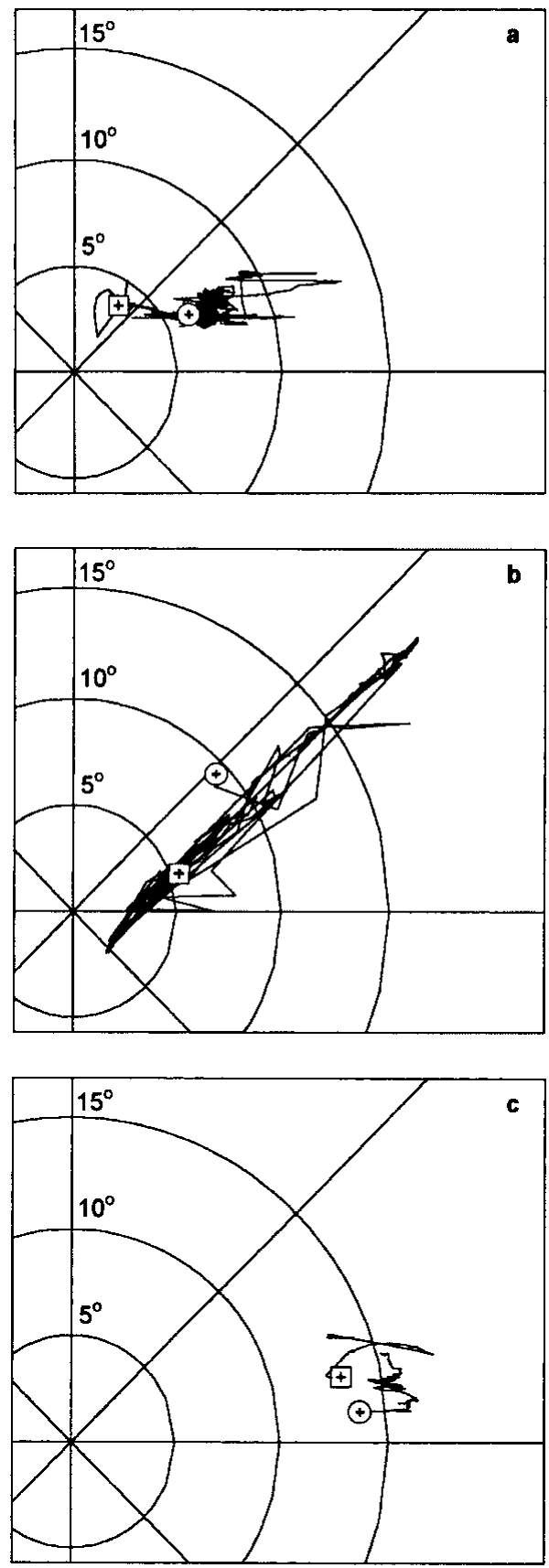

Fig. 6. The total path of the tiltmeter axis projected on a horizontal plane (i.e. the $x-y$ plane in Fig. 3a) Tiltmeter at the interface ( $a$ ), $1 \mathrm{~m}$ below it $(b)$ and $2 \mathrm{~m}$ below it ( $c$ ). The open circles mark the start, and the open squares the end, of the record. The circles are contour lines of total tilt.

These measurements show that the piezometer in the till stayed hydraulically connected to the borehole for at least that long, as no phase lags and no attenuation of high-frequency variations were observed. The transducer at $150 \mathrm{~m}$ below the surface is subject to systematic errors, which explains the shift afterJD 195.

\section{Engineering properties of a till sample}

A cylindrical till matrix sample $11 \mathrm{~cm}$ long and $5 \mathrm{~cm}$ in diameter was recovered from the top of the till layer in hole N1A. The sample contained some ice, and a water content of $29 \%$ was measured after it was allowed to melt. Sieving showed that only $6 \%$ of the sample's weight is in the silt-andclay fraction (Truffer and others, 1999). The remolded till was tested in a triaxial apparatus and an oedometer. In addition, 
$70 \mathrm{~m}$

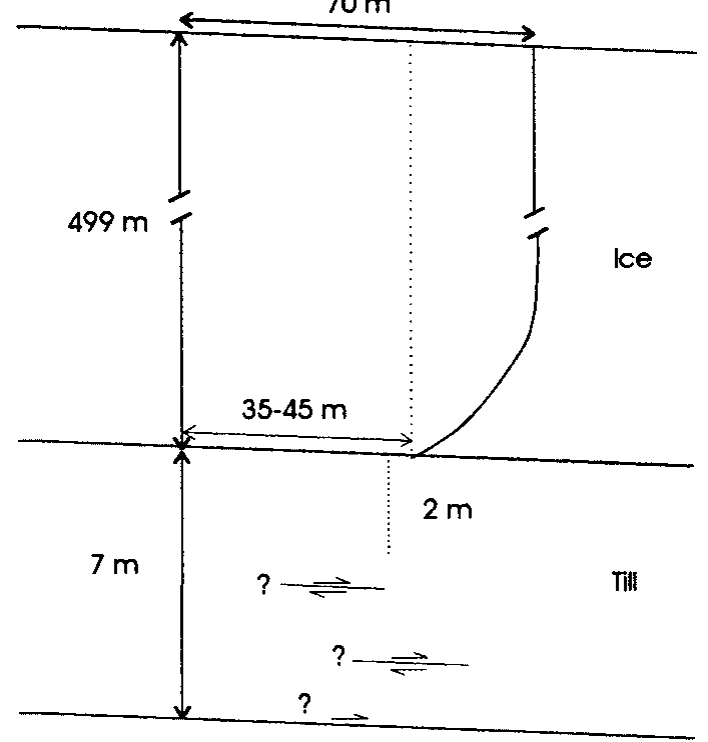

Fig. 7. Diagram showing the inferred distribution of glacier motion over the 410 day measurement period. Fifty to seventy per cent of the observed motion occurs below $2 \mathrm{~m}$ in the till, either on a series of shear bands or at the till-bedrock interface.

an Atterberg liquid limit of $10 \%$ was determined in a liquidlimit testing device (Bowles, 1992). Table 1 summarizes the results. The friction angle $\phi$ and the apparent cohesion $c_{\mathrm{a}}$ define a linear relationship (Coulomb friction law) between the sample strength $\tau$ and the effective pressure $\sigma^{\prime}$ :

$$
\tau=c_{\mathrm{a}}+\sigma^{\prime} \tan \phi
$$

(e.g. Lambe and Whitman, 1979). The low apparent cohesion is expected for a granular material, but previously measured friction angles on glacial till were typically $<30^{\circ}$ (Iverson and others, 1998). Our high value reflects the low silt-and-clay content (Lambe and Whitman, 1979) and the high angularity (data by D. B. Simons shown in Julien (1995, fig. 7.2)), although it might have been caused by a few large particles that were not removed before the test. The in situ diffusivity of the till is likely to be lower than that measured in the oedometer due to the inferred presence of ice in the uppermost part of the till (Truffer and others, 1999).

Ring-shear testing was done by S. Tulaczyk at the California Institute of Technology, Pasadena, CA, to test the strain-rate dependence of the shear strength. The shear strength increased by only $2 \mathrm{kPa}$ (from 21 to $23 \mathrm{kPa}$ ) as the strain rates were varied over two orders of magnitude, reflecting a highly non-linear nature of the till. The slight increase in shear stress may reflect strain-rate-induced variations of effective pressure, and not a viscous effect (Kamb, 1991; Tulaczyk and others, 2000). All ring-shear tests were carried out at the same low normal load of $20 \mathrm{kPa}$. They give a second estimate of the friction angle equal to $45^{\circ}$. This somewhat higher value is caused by the walls of the ring-shear device (Iverson and others, 1997).

\section{Table 1. Engineering properties of a till sample from borehole} $\mathcal{N} 1 A$

\section{Soil density}

Water content

Liquid limit

Friction angle

Apparent cohesion

Hydraulic diffusivity

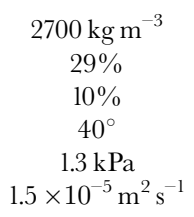

\section{DISGUSSION}

In this section we will first discuss alternative interpretations of our data, and then give a tentative explanation for shortterm fluctuations in the record. After discussing a mechanism that can explain motion on shear layers deep within the till, we go on to discuss the glaciological consequences of these findings, in particular for erosion and the surge mechanism.

\section{Alternative interpretations of the data}

In the above section we have concluded that most of the observed surface motion originates from $>2 \mathrm{~m}$ below the ice-till interface. We have considered several other possibilities, such as failure of the instruments, pulling of the instruments out of the till and misinterpretation of a dirty basal ice layer as water-saturated basal till. None of these possibilities can satisfactorily explain the results. If, for some reason, the instruments were placed in the basal ice rather than in the till, a steady tilting of much higher magnitude would be expected. The most likely alternative interpretation is that a substantial amount of basal motion occurs as sliding at the ice-till interface (Fig. 8). This could be the case under three conditions. First, the uppermost tiltmeter would have to be placed far enough from the ice-till interface not to be affected by the sliding motion. This is a possibility due to the uncertainties in the emplacement (see Methods). Second, the sliding motion would not have destroyed the cable. In principle, this is a possibility, but it would require that the induced stretch be distributed over the entire length of the cable. It could then conceivably stretch up to $150 \mathrm{~m}$, substantially more than the 35-45 $\mathrm{m}$ required from basal motion. It seems rather unlikely, however, that the cable survived such an intense shearing environment for well over a year, a view shared by the manufacturer (personal communication from J. Dower, Cortland Cable Company, 1999). And, third, the instruments would have to be firmly emplaced in a very strong till. If they were not firmly emplaced, they would be pulled out of the till and into the ice. Although ice deformation accounts for only half or less of the total surface motion, calculated tilting rates

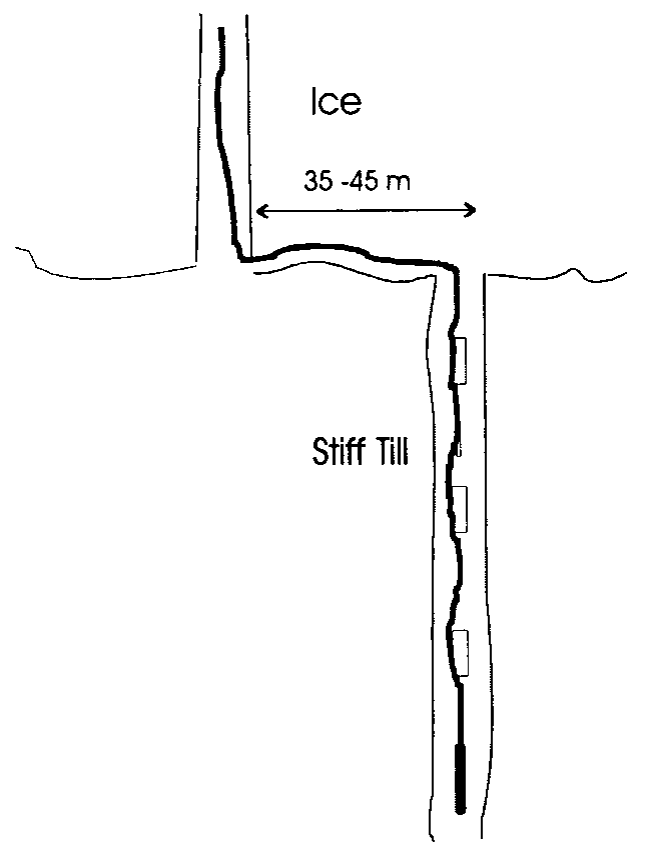

Fig. 8. Position of the instruments if most of the basal motion is occurring on a discrete sliding plane or in a thin layer of sediments. 
at the bottom of the glacier would be significantly higher than those recorded by the tiltmeters. If the instruments had been pulled out of the till, one after the other would have recorded higher tilting rates. If the till was not strong, the instruments would be dragged through the deformable till, again causing appreciable amounts of tilting in one instrument after the other. This is not observed. On the other hand, the tiltmeter at $1 \mathrm{~m}$ below the interface exhibits several excursions of up to $15^{\circ}$ of tilt. Also, the lowermost tiltmeter jumps by about $5^{\circ}$ on 25 May 1998 (Fig. 5). At about this time the spring speed-up is expected to occur (Fig. 4), although we have no direct observations of this from 1998. The other tiltmeters do not record this event, or at least not as clearly. This observation fits very well with the idea of shear layers below the instruments, but not so well with the idea of a strong till and a sliding interface between the ice and the till.

\section{Short-term fluctuations}

We tested the idea that a diffusing water-pressure wave affected the till strength (Fischer and others, 1998) and thus some of the structure in the tiltmeter record (Tulaczyk, 1999; Tulaczyk and others, 2000). We assumed that the pore-water pressures in the till are driven by a fluctuating water pressure at the ice-till interface. The water pressure beneath a valley glacier normally drops to a minimum in summer, once a good drainage system is established (Fig. 5). This increases the effective pressure in the upper part of the till, making it stronger. Underlying till will still be at higher pore-water pressures and therefore lower effective pressures. Thus, it will deform more readily. We modeled pore-water pressures in the till by numerically solving the one-dimensional diffusion equation

$$
\frac{\partial^{2} p}{\partial z^{2}}=C_{\mathrm{v}} \frac{\partial p}{\partial t}
$$

(De Marsily, 1986), where $p$ is the pore-water pressure and $C_{\mathrm{v}}$ is the hydraulic diffusivity of the till. The measured water pressures were prescribed at the top of the till layer, interpolating through the data gap and assuming the pressures have a periodicity of 1 year. A zero gradient of hydraulic head was assumed at the bottom. We then compared the modeled results with a smoothed record of measured tilts (Fig. 9). The largest changes in tilt are observed at the time when the low-water-pressure wave reaches the corresponding tiltmeter, but otherwise the correlation between the two curves is not strong. The best agreement between the curves was obtained when a hydraulic diffusivity of $3 \times 10^{-7}$ $\mathrm{m}^{2} \mathrm{~s}^{-1}$ was used, and 5 day averages of tilts were plotted. The diffusivity is somewhat smaller than that measured on a sample $\left(10^{-5} \mathrm{~m}^{2} \mathrm{~s}^{-1}\right)$, but due to the inferred presence of ice in the uppermost part of the till layer, we expect that the laboratory test overestimated the hydraulic diffusivity (Truffer and others, 1999).

Although the contribution of the overall measured tilt rate to the surface motion is negligible, each of the tiltmeters indicates periods of high strain rates, both positive and negative. Such variations have been observed before (Blake, 1992), and have been interpreted as elastic effects, due to changing local basal shear stress (Iverson and others, 1999) or effective stress (Tulaczyk and others, 2000). Such elastic effects are predicted by an elastic--plastic soil model if stress changes are not large enough to exceed a previously reached maximum (e.g. Wood, 1990). Nolan and Echelmeyer (1999b) concluded that lake-drainage events cause hydraulic jacking

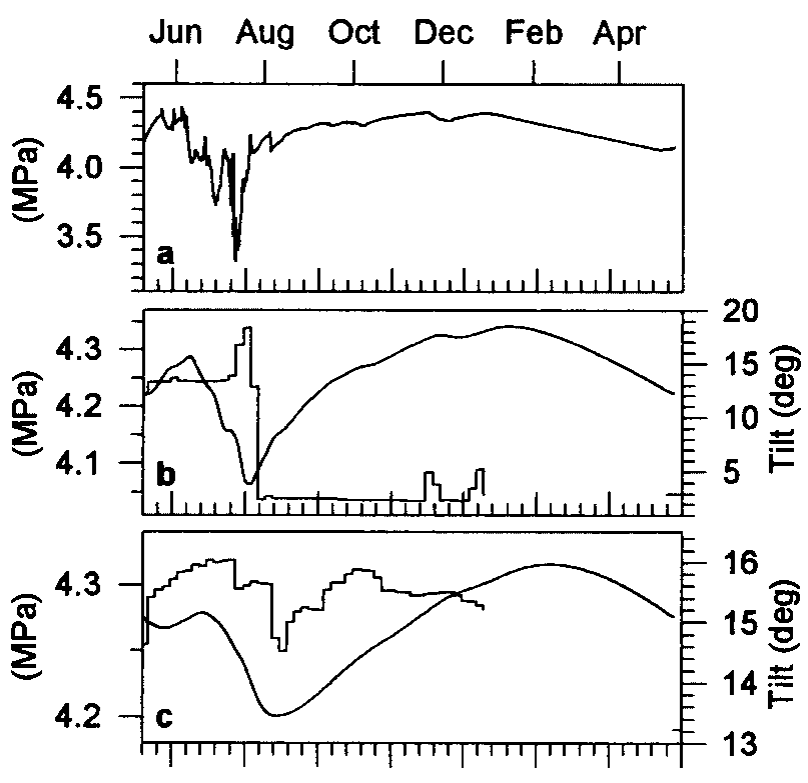

150200250300350400450500

\section{Day of the year 1997}

Fig. 9. (a) Observed water pressure used as input for the model. (b, c) Modeled pore-water pressures and averaged total tilt (step plot) $1 \mathrm{~m}(\mathrm{~b})$ and $2 \mathrm{~m}(\mathrm{c})$ below the interface.

and temporary changes in local ice-overburden pressure. Together with changes in the pore-water pressure and local shear stresses, rather dramatic switches in the stress state should be expected.

It should be kept in mind that the small-scale features in the tiltmeter record are much harder to interpret because the tiltmeters are connected with a cable. The cable allows for a certain amount of interaction between the instruments, and some of the tilting could be due to pulling on the cable.

The tiltmeter record indicates that basal motion due to shearing in the upper $2 \mathrm{~m}$ of the till amounts to only $13 \mathrm{~cm}$ in 410 days. Fifty to seventy per cent of the glacier's surface motion occurs more than $2 \mathrm{~m}$ beneath the ice-till interface. The total tilts reported above are fortuitously small, since tilt events as large as $20^{\circ}$ are observed (Fig. 5). A uniform tilt of $20^{\circ}$ would still only amount to $0.7 \mathrm{~m}$ of basal motion, a negligible amount.

\section{Motion deep in a till layer: other observations}

Direct observations of the distribution of motion in till layers have been made in tunnels near the glacier terminus (Boulton and Hindmarsh, 1987; Echelmeyer and Wang, 1987). Echelmeyer and Wang observed shear bands in the frozen subglacial till beneath Ürümqi Glacier No.1, and concluded that $10-25 \%$ of the total surface motion occurred on such bands. The present study concludes that an even larger amount of motion can occur deep in the till layer of a relatively fast-moving temperate glacier. In retrospect, several other observations also fit into this picture. Harrison and others (1986) used borehole television on surge-type Variegated Glacier, Alaska, and were surprised that they did not manage to measure significant motion across the ice-till interface. Iverson and others (1999) attributed the lack of significant till deformation in the upper $20 \mathrm{~cm}$ of the till layer to sliding of the ice over the underlying till, but did allow that it could also be due to motion deeper in the till.

In a study of the Puget glacial lobe, Washington, U.S.A., 
Brown and others (1987) concluded that "basal motion was confined to the ice-bed interface or to distinct faults within the substrate", and that "shearing along discrete shear zones is evident and may amount to significant displacement" (Brown and others, 1987, p. 8994). Hiemstra and Van der Meer (1997) also concluded that glacial deposits from Wijnjewoude in The Netherlands contained discrete horizontal to sub-horizontal shear zones, along which strain was focused. Astakhov and others (1996) reported observations of shear bands in West Siberian permafrost that was formerly overlain by glaciers. The occurrence of such discrete shear zones in glacial deposits has thus become textbook knowledge in glacial geology (e.g. Menzies and Shilts, 1996, p. 48), although it has not been possible to show the amount of displacement that occurs in such zones.

Alley (1991) presented arguments for widespread till deformation beneath the Laurentide ice sheet. This contrasts with the view of Clayton and others (1989) who argue against pervasive till deformation on the basis of till stratigraphy. It is also often assumed that coherent thrust sheets imply a frozen bed (e.g. Mickelson and others, 1983). The results presented in this paper might help resolve these paradoxes by allowing slip across discrete planes deep within unfrozen till layers. Such deep-seated slip may also help explain observations of large till sheets (up to $1000 \mathrm{~km}^{2}$ ) which have been displaced up to $250 \mathrm{~km}$ with little apparent internal deformation (references in Van der Wateren, 1995, p. 328 ).

Discrete shear zones are also observed in shear tests on granular materials (e.g. Mandl and others, 1977).

\section{Is till deformation at $>2 \mathrm{~m}$ depth physically plausible?}

The question of till deformation is intimately linked with that of the strength of the ice-till interface (Alley, 1983; Brown and others, 1987; Iverson, 1999; Tulaczyk, 1999). These studies show that this strength depends on the size of clasts and the grain-sizes in till, and on the effective pressure at the interface. An interface between ice and coarse clast-rich till, such as the one encountered beneath Black Rapids Glacier, is expected to have a high strength, thus making till deformation more probable. The inferred presence of regelation ice in the upper part of the till (Truffer and others, 1999) only serves to make this coupling stronger.

Tulaczyk (1999) described three different models of basal motion over a water-saturated till: sliding over the till, shear deformation at a depth that is determined by the minimum effective pressure (overburden minus pore-water pressure) and shear deformation at a depth determined by the minimum of the past maximum effective pressure. The last model, "the perfectly overconsolidated till", takes into account the memory of a granular material. When subjected to a shear load, a granular material will exhibit a peak strength that is determined by the maximum effective pressure it has experienced since it was last disturbed. If this maximum is higher than the current effective stress, the till is called overconsolidated (Clarke, 1987). The maximum effective pressure is the difference between the overburden pressure, which increases linearly with depth in the till, and the minimum in water pressure over a given time period at a certain depth. This minimum water pressure increases with depth due to diffusion. To model the depth dependence of the maximum effective pressure throughout the year, the water pressure was calculated by solving Equation (1) for a $7 \mathrm{~m}$ thick till of hydraulic diffusivity $C_{\mathrm{v}}=3 \times 10^{-7} \mathrm{~m}^{2} \mathrm{~s}^{-1}$ and density $\rho_{\text {till }}=2700 \mathrm{~kg} \mathrm{~m}^{-3}$. Figure 10 shows the resulting annual maximum effective pressure as a function of depth. A strong decrease in the first $2 \mathrm{~m}$ is followed by a broad minimum at around $3.5 \mathrm{~m}$ and an asymptotic decrease that reflects the increasing overburden pressure. The position of this minimum in the annual maximum effective pressure reflects the position of the smallest value of peak strength, and marks a likely place for a shear layer. Using a hydraulic diffusivity of $C_{\mathrm{v}}=$ $10^{-5} \mathrm{~m}^{2} \mathrm{~s}^{-1}$ (Table 1) places such a layer even deeper in the basal zone, at $4.6 \mathrm{~m}$ below the ice-till interface.

In a proper model of basal motion, the strength of the till-bedrock interface has to be considered as well. It is possible that this interface is rather smooth, and that it is the weakest point in the basal ice-till-bedrock system. Sliding of till over bedrock has been discussed by Cuffey and Alley (1996) and Hindmarsh (1996).

\section{Erosion and till mass balance}

The glacier's main accumulation area lies to the south of the Denali Fault from where it crosses into the main fault valley about $3 \mathrm{~km}$ upstream of the drill site. In Truffer and others (1999) we concluded that about $85 \%$ of the till sampled in the boreholes was derived from the northern side of the fault. On the northern side or along this fault the glacier extends between $7 \mathrm{~km}$ (ice divide) and $12 \mathrm{~km}$ (head of the westernmost tributary) upstream from the drill site (Fig. 1). If 2$7 \mathrm{~m}$ of till were to be carried along at the rate of the basal motion, the average upstream erosion rate would be 4 $30 \mathrm{~mm} \mathrm{a}^{-1}$, ignoring cross-sectional variations and till focusing towards the center of the channel. This is somewhat higher than is thought to be typical of alpine glaciers (e.g. Bennett and Glasser, 1996), but agrees well with the high rates found in southeast Alaska (Hallet and others, 1996). Humphrey and Raymond (1994) found that the erosion rate on Variegated Glacier was directly proportional to the ice velocity. They calculated a dimensionless erosion rate - the ratio of erosion rate to ice velocity - on the order of $10^{-4}$ for Variegated Glacier, and they showed that a similar rate was found for Glacier d'Argentière, France, and Breiðamerkurjokull. If this ratio applied at Black Rapids Glacier, an erosion rate of $6 \mathrm{~mm} \mathrm{a}^{-1}$ would result, just at the lower limit of the above estimate. It is possible that sliding of till over the underlying bedrock is the erosional mechanism for supplying this substantial amount of till (Cuffey and Alley, 1996; Hindmarsh, 1996). The presence of large clasts and boulders

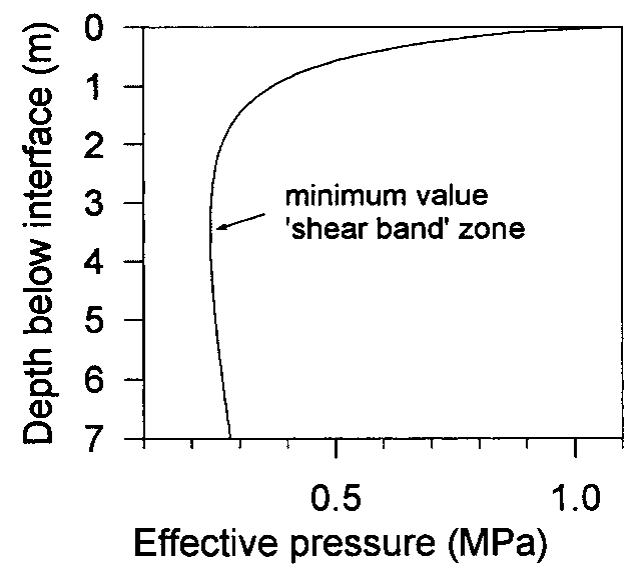

Fig. 10. Maximum effective pressure throughout the year as a function of depth. Overburden pressure increases linearly with depth. The annual minimum of the water pressure was calculated by solving a diffusion equation. 
in the till (Truffer and others, 1999) shows that abrasion cannot be the only erosional mechanism, however, and plucking has to occur as well.

\section{Implications for surge behavior}

Black Rapids is a surge-type glacier, and naturally the question arises if our observations can bring us a step closer to understanding surge behavior and initiation. The fast motion during the 1982/83 surge of Variegated Glacier was accompanied by water pressures close to overburden (Kamb and others, 1985). Dye-tracing experiments indicated a complete switch from a fast to a slow drainage system between non-surge and surge conditions (Brugman, 1986), and large volumes of water were released at times of decreasing velocities (Humphrey and Raymond, 1994). This has also been observed at the surge termination of Kolka Glacier, Caucasus (Krenke and Rototayev, 1973) and West Fork Glacier, Alaska (Harrison and others, 1994). Kamb's (1987) model of a switch from a drainage system consisting of Röthlisberger ( $R$ ) channels to a linked cavity system can account for these observations. It assumes that the glacier is underlain mainly by clean bedrock, however, most likely a significant oversimplification (Harrison and others, 1986; Humphrey and Raymond, 1994; Truffer and others, 1999).

We suggest that a switch in the drainage system is not the cause but rather an effect of fast glacier motion. Surges could be initiated by the large-scale mobilization of subglacial till. This would happen as basal shear stresses exceed a critical value (Boulton and Jones, 1979; Clarke and others, 1984). Increasing shear stresses were observed on Variegated Glacier prior to the 1982/83 surge (Raymond and Harrison, 1988). An efficient drainage system, such as one consisting of $\mathrm{R}$ channels, will presumably be destroyed by high basal motion, causing a switch to a slowly draining system, such as the distributed "canals" suggested by Walder and Fowler (1994), with a substantial amount of water storage and high basal water pressures. This makes sustained fast motion possible. The sudden release of the stored water will cause an abrupt slowdown or an end to the surge. The interaction between the subglacial hydraulic system and basal motion in the context of till mechanics is not understood well enough to elaborate further.

The mechanism suggested here is in accord with observations made on the surging Variegated Glacier, and it emphasizes the role of a subglacial till layer. It establishes the presence of a highly erodible glacier bed as a necessary but not sufficient condition for glacier surging, as has been proposed before (Wilbur, 1988; Hamilton and Dowdeswell, 1996). A glacier geometry that allows the build-up of high basal shear stresses is possibly a second necessary condition.

\section{GONGLUSION}

Results from surface motion measurements, borehole inclinometry and tiltmeters installed in the till beneath Black Rapids Glacier reveal that $50-70 \%$ of the observed surface motion occurs at depths of $>2 \mathrm{~m}$ in the till layer. This study was conducted in the most active area of the glacier, where the observed surface motion is large, and where a $7 \mathrm{~m}$ thick subglacial till layer exists. It is possible that the basal motion occurs on a system of discrete shear zones or at the till-bedrock interface. Shear zones at relatively large depths can be explained with a simple model of "perfectly overconsolidated material" and diffusion of water pressure into the till.

The small-scale structure of the tiltmeter record can be tentatively explained, although the interpretation is much more difficult and involves more assumptions. At any rate, most of the observed tilting events are reversible, and the total measured tilt corresponds to only $13 \mathrm{~cm}$ of basal motion (within the $2 \mathrm{~m}$ sampled) over the 410 days of measurements, as compared to the $70 \mathrm{~m}$ observed at the surface.

The observation that the upper part of the till layer is not deforming substantially is difficult to reconcile with a viscous model of the till which would require decreasing deformation rates with depth. The heterogeneity of the subglacial till (Truffer and others, 1999) cautions against applying simple continuum mechanical concepts to the study of this material.

The results of this field study have implications for the interpretation of the geologic record, such as far-traveled till sheets and the pervasive deformation vs soft till debate on the southern Laurentide ice sheet.

Our observations suggest that the large-scale mobilization of subglacial sediments plays a dominant role in the surge mechanism. Such mobilization could occur as the glacier reaches a "surge geometry" at which a critical basal shear stress is reached. Taking a broader view, the mechanisms of velocity variation on several time-scales observed on Black Rapids (Heinrichs and others, 1996) and many other glaciers (Willis, 1995) also need to be examined within the framework of our observations, but to do so is beyond the scope of this paper.

This study, among many others, shows the importance of basal processes in the understanding of glacier dynamics. It could be argued that a knowledge of till rheology is at least as important as that of ice rheology, and that the till mass balance, perhaps conventionally considered within the realm of glacial geology and geomorphology, is as important to the dynamics of the glacier as is the more familiar surface mass balance. More specifically, our study shows that it is important to consider the full extent of the till layer, and not just the uppermost few centimeters. This is a challenge to both field and theoretical studies.

\section{ACKNOWLEDGEMENTS}

We would like to thank S. Tulaczyk, then at the California Institute of Technology, for helping with the various soil tests, and R. F. Scott of the Division of Engineering and Applied Science, also at Caltech, for allowing us to use his soil-testing equipment. L. Fruth and the management of Earth Technology Inc. in Irvine, California, made their triaxial testing laboratory available. Thanks to all the helpers in the field. We appreciate the valuable reviews by $\mathrm{N}$. Iverson, K. Cuffey and G. K. C. Clarke who pointed us to some relevant references, and to A. Iken who read an earlier version of the paper. This research was funded by grant OPP 9423477 of the U.S. National Science Foundation.

\section{REFERENGES}

Alley, R. B. 1989. Water-pressure coupling of sliding and bed deformation: II. Velocity-depth profiles. F. Glaciol., 35(119), 119-129.

Alley, R. B. 1991. Deforming-bed origin for southern Laurentide till sheets? 7. Glaciol., 37(125), 67-76.

Alley, R. B., D. D. Blankenship, C. R. Bentley and S.T. Rooney. 1986. 
Deformation of till beneath Ice Stream B, West Antarctica. Nature, 322(6074), 57-59.

Astakhov, V. I., F. A. Kaplyanskaya and V. D. Tarnogradskiy. 1996. Pleistocene permafrost of west Siberia as a deformable glacier bed. Permafrost and Periglacial Processes, 7, 165-191.

Bennett, M. R. and N. F. Glasser. 1996. Glacial geology: ice sheets and landforms. Chichester, etc., John Wiley \& Sons.

Blake, E.W. 1992. The deforming bed beneath a surge-type glacier: measurement of mechanical and electrical properties. (Ph. D. thesis, University of British Columbia.)

Blake, E., G. K. C. Clarke and M. C. Gérin. 1992. Tools for examining subglacial bed deformation. 7. Glaciol., 38(130), 388-396.

Blake, E.W., U. H. Fischer and G. K. C. Clarke. 1994. Direct measuremen of sliding at the glacier bed. F. Glaciol., 40(136), 595-599.

Blankenship, D. D., C. R. Bentley, S. T. Rooney and R. B. Alley. 1986. Seismic measurements reveal a saturated porous layer beneath an active Antarctic ice stream. Nature, 322(6074), 54-57.

Boulton, G. S. and R. C. A. Hindmarsh. 1987. Sediment deformation beneath glaciers: rheology and geological consequences. 7. Geophys. Res., 92(B9), 9059-9082.

Boulton, G. S. and A. S. Jones. 1979. Stability of temperate ice caps and ice sheets resting on beds of deformable sediment. F. Glaciol., 24(90), 29-43.

Bowles, J. E. 1992. Engineering properties of soils and their measurement. Fourth edition. New York, McGraw-Hill Inc.

Brown, N. E., B. Hallet and D. B. Booth. 1987. Rapid soft bed sliding of the Puget glacial lobe. F. Geophys. Res., 92(B9), 8985-8997.

Brugman, M. M. 1986. Water flow at the base of a surging glacier. (Ph.D. thesis, California Institute of Technology, Pasadena, California.)

Clarke, G. K. C. 1987. Subglacial till: a physical framework for its properties and processes. F. Geophys. Res., 92(B9), 9023-9036.

Clarke, G. K. C., S. G. Collins and D. E. Thompson. 1984. Flow, thermal structure, and subglacial conditions of a surge-type glacier. Can. F. Earth Sci., 21 (2), 232-240.

Clayton, L., D. M. Mickelson and J.W. Attig. 1989. Evidence against pervasively deformed bed material beneath rapidly moving lobes of the southern Laurentide ice sheet. Sediment. Geol., 62(3-4), 203-208.

Cuffey, K. and R. B. Alley. 1996. Is erosion by deforming subglacial sediments significant? (Toward till continuity.) Ann. Glaciol., 22, 17-24.

De Marsily, G. 1986. Quantitative hydrogeology. San Diego, CA, Academic Press Inc.

Echelmeyer, K. and Wang Zhongxiang. 1987. Direct observation of basal sliding and deformation of basal drift at sub-freezing temperatures. $\mathcal{F}$ Glaciol., 33(113), 83-98.

Engelhardt, H. and B. Kamb. 1998. Basal sliding of Ice Stream B, Wes Antarctica. 7. Glaciol., 44(147), 223-230.

Engelhardt, H. F., W. D. Harrison and B. Kamb. 1978. Basal sliding and conditions at the glacier bed as revealed by bore-hole photography. F. Glaciol., 20(84), 469-508.

Engelhardt, H., N. Humphrey, B. Kamb and M. Fahnestock. 1990. Physical conditions at the base of a fast moving Antarctic ice stream. Science, 248(4951), 57-59.

Fischer, U. H. and G. K. C. Clarke. 1994. Ploughing of subglacial sediment. 7. Glaciol., 40 (134), 97-106.

Fischer, U. H., N. R. Iverson, B. Hanson, R. LeB. Hooke and P. Jansson. 1998 Estimation of hydraulic properties of subglacial till from ploughmeter measurements. f. Glaciol., 44(148), 517-522.

Hallet, B., L. E. Hunter and J. Bogen. 1996. Rates of erosion and sedimen evacuation by glaciers: a review of field data and their implications. Global and Planetary Change, 12(1-4), 213-235.

Hamilton, G. S. and J. A. Dowdeswell. 1996. Controls on glacier surging in Svalbard. F. Glaciol., 42(140), 157-168.

Harrison, W. D. and B. Kamb. 1973. Glacier bore-hole photography. F. Glaciol., 12(64), 129-137.

Harrison, W. D., B. Kamb and H. Engelhardt. 1986. Morphology and motion at the bed of a surge-type glacier. Abstract. Eidg. Tech. Hochschule, Zürich. Versuchsanst. Wasserbau, Hydrol. Glaziol. Mitt. 90, 55-56.

Harrison, W. D., K. A. Echelmeyer, E. F. Chacho, C. F. Raymond and R. J. Benedict. 1994. The 1987-88 surge of West Fork Glacier, Susitna Basin, Alaska, U.S.A. 7. Glaciol., 40(135), 241-254.

Heinrichs, T. A., L. R. Mayo, K. A. Echelmeyer and W. D. Harrison. 1996. Quiescent-phase evolution of a surge-type glacier: Black Rapids Glacier, Alaska, U.S.A. J. Glaciol., 42(140), 110-122.

Hiemstra, J. F. and J. J. M. van der Meer. 1997. Pore-water controlled grain fracturing as an indicator for subglacial shearing in tills. f. Glaciol., 43(145), 446-454.

Hindmarsh, R. C. A. 1996. Sliding of till over bedrock: scratching, polishing, comminution and kinematic-wave theory. Ann. Glaciol., 22, 41-47.
Hooke, R. LeB., B. Hanson, N. R. Iverson, P. Jansson and U. H. Fischer. 1997. Rheology of till beneath Storglaciären, Sweden. f. Glaciol., 43(143), 172-179.

Humphrey, N. F. and C. F. Raymond. 1994. Hydrology, erosion and sediment production in a surging glacier: Variegated Glacier, Alaska, 198283. F. Glaciol., 40 (136), 539-552.

Iverson, N. R., R.W. Baker and T. S. Hooyer. 1997. A ring-shear device for the study of till deformation: tests on tills with contrasting clay contents. Quat. Sci. Rev., 16(9), 1057-1066.

Iverson, N. R., T. S. Hooyer and R. W. Baker. 1998. Ring-shear studies of till deformation: Coulomb-plastic behavior and distributed strain in glacier beds. F. Glaciol., 44(148), 634-642.

Iverson, N. R., R. W. Baker, R. LeB. Hooke, B. Hanson and P. Jansson. 1999. Coupling between a glacier and a soft bed. I. A relation between effective pressure and local shear stress determined from till elasticity. 7. Glaciol., 45(149), 31-40.

Julien, P.Y. 1995. Erosion and sedimentation. Cambridge, Cambridge University Press.

Kamb, B. 1987. Glacier surge mechanism based on linked cavity configuration of the basal water conduit system. F. Geophys. Res., 92(B9), 9083-9100.

Kamb, B. 1991. Rheological nonlinearity and flow instability in the deforming bed mechanism of ice stream motion. 7. Geophys. Res., 96(B10), $16,585-16,595$.

Kamb, B. and K. A. Echelmeyer. 1986. Stress-gradient coupling in glacier flow: I. Longitudinal averaging of the influence of ice thickness and surface slope. 7. Glaciol., 32(111), 267-284.

Kamb, B. and 7 others. 1985. Glacier surge mechanism: 1982-1983 surge of Variegated Glacier, Alaska. Science, 227(4686), 469-479.

Knight, P. G. 1999. Glaciers. Cheltenham, Stanley Thornes (Publishers) Ltd.

Krenke, A. N. and K. P. Rototayev. 1973. A surge of the Kolka Glacier and its hydrometeorological consequences. International Association of Hydrological Sciences Publication 107 (Symposium at Banff 1972 - The Role of Snow and Ice in Hydrology), Vol. 2, 1160-1171.

Lambe, T.W. and R.V. Whitman. 1979. Soil mechanics. New York, etc., John Wiley and Sons.

Mandl, G., L. N. J. de Jong and A. Maltha. 1977. Shear zones in granular material - an experimental study of their structure and mechanical genesis. Rock Mech., 9, 95-144.

Menzies, J. and W.W. Shilts. 1996. Subglacial environments. In Menzies, J., ed. Past glacial environments - sediments, forms and techniques. Glacial environments. Vol. 2. Oxford, etc., Butterworth-Heinemann, 15-136.

Mickelson, D. M., L. Clayton, D. S. Fullerton and H.W. Borns, Jr. 1983. The Late Wisconsin glacial record of the Laurentide ice sheet in the United States. In Wright, H.E., Jr, ed. Late-Quaternary environments of the United States. Vol. 1. Porter, S.C., ed. The Late Pleistocene. Minneapolis, MN, University of Minnesota Press, 3-37.

Nolan, M. and K. Echelmeyer. 1999a. Seismic detection of transient changes beneath Black Rapids Glacier, Alaska, U.S.A.: I. Techniques and observations. F. Glaciol., 45(149), 119-131.

Nolan, M. and K. Echelmeyer. 1999b. Seismic detection of transient changes beneath Black Rapids Glacier, Alaska, U.S.A.: II. Basal morphology and processes. f. Glaciol., 45(149), 132-146.

Raymond, C. F. and W. D. Harrison. 1988. Evolution of Variegated Glacier, Alaska, U.S.A., prior to its surge. f. Glaciol., 34(117), 154-169.

Truffer, M., R. J. Motyka, W. D. Harrison, K. A. Echelmeyer, B. Fisk and S. Tulaczyk. 1999. Subglacial drilling at Black Rapids Glacier, Alaska, U.S.A.: drilling method and sample descriptions. F. Glaciol., 45(151), 495-505.

Tulaczyk, S. 1999. Ice sliding over weak, fine-grained tills: dependence of ice-till interactions on till granulometry. In Mickelson, D. M. and J.V. Attig, eds. Glacial processes: past and present. Boulder, CO, Geological Society of America, 159-177. (Special Paper 337.)

Tulaczyk, S. M., B. Kamb and H. F. Engelhardt. 2000. Basal mechanics of Ice Stream B, West Antarctica. I. Till mechanics. 7. Geophys. Res., 105(B1), 463-481.

Van der Wateren, F. M. 1995. Processes of glaciotectonism. In Menzies, J., ed. Modern glacial environments - processes, dynamics and sediments. Glacial environments. Vol. 1. Oxford, etc., Butterworth-Heinemann, 309-335.

Walder, J. S. and A. Fowler. 1994. Channelized subglacial drainage over a deformable bed. 7. Glaciol., 40(134), 3-15.

Wilbur, S.W. 1988. Surging versus non-surging glaciers: a comparison using morphometry and balance. (M.Sc. thesis, University of Alaska Fairbanks.)

Willis, I. C. 1995. Intra-annual variations in glacier motion: a review. Prog. Phys. Geogr., 19(1), 61-106.

Wood, D. M. 1990. Soil behaviour and critical state soil mechanics. Cambridge, Cambridge University Press. 